\title{
Brand Communication through Facebook Altering Consumer Psychology
}

\author{
Ms. Priya Handa ${ }^{1}$, Dr. Mamata Mahapatra ${ }^{2}$ and Dr. Anubhuti Yadav ${ }^{3}$
}

\begin{abstract}
The purpose of this research is to study the positivity of brand communication with the emergence of Facebook, and to understand the alterations and modifications in consumer psychology by brand communication through Facebook. Descriptive study using literature review from the period of 2011-2017 from database of EBSCO, Emerald, Sage, etc. The results discovered that brand communication is positively affected by Facebook as it gives an amplified-dais to the brands to function excellently. It is a consumer involvement and endorsing apparatus and has chief impact on tempting and maintaining a fan base. Facebook has emerged as platform which gives brand a podium for expression, up-gradation, communication, elevation, and boosts their brand image, equity and loyalty. Facebook empowers the deep consumers' instincts which not only alters consumer's consumer psychology but changes their complete lifestyle. Moreover, a strong relation between brand communications through brand Facebook pages and consumers was found. It is recommended that brand managers mustpractice Facebook for mass interactivity as it offers wide prospects to progress brands and creates strong connect with online consumer's psychology and made brand communication innovative.
\end{abstract}

Keywords: Facebook, Consumer Psychology, Brand Communication, Facebook Branding, Consumer Behaviour, social networking, brand image, digital marketing.

\section{Introduction}

This study has focused on how Facebook has evolved communication patterns as well as significantly affecting and changing consumer psychology with full time engagement activities in terms of brand communication and has bought changes to their buying intents. The study lays emphasis on how brand communication has been changed rapidly with the emergence of social media website Facebook. Facebook offers a public stage to the masses to share, comment, recommend and expressing their views, opinions, attitudes and gives a virtual experience of the brand before going for the final purchase. The researcher has taken two main hypotheses in this study. First, that brand communication is positively affected by Facebook, and second that there is positive change in consumer psychology by brand communication through Facebook. The study has discussed the vital role played by Facebook in brand communication these days and how with the diffusion of innovative technology Facebook has changed the communication patterns overall. Facebook has emerged as the only platform which gives every brand a stage for

${ }^{1}$ Associate Professor, Centre Head for Organisational psychology, Amity Institute of Psychology and Allied Sciences, Amity University

${ }^{3}$ Head of Department of New Media and Information Technology, Associate Professor, New Media, Indian Institute of Mass Communication, New Delhi, IIMC, Delhi expression, communication, promotion, and helps in enhancement of their brand image, equity and reveal their personality. The other aspect of study has put light on how online users/ consumers are influenced and have deep effect on their buying behaviour which leads to psychological change in their changed lifestyle, attitudes and perceptions which contributes to their evolved modified thinking process.

The study comprises of in-depth study of how Facebook has contributed to the changes in brand image and attitude in the minds of consumers. The researcher has explored the Facebook as a solid interface for brand communication which reflects brand personality and adds to brand equity. The study has discussed that how Facebook is creating a network of experience, connect and networking and platform for consumers and brands to meet at a common ground. Facebook is building important operationality for businesses and has bought a revolutionary change in the digital marketing patterns of brands overall. This study will focus on the consumers that how brand communication through Facebook has transformed their lifestyle and made Facebook an integral part of their lives. Facebook helps in a great way in making a bridge between Facebook and user which helps consumers and brands in entire transformation of their communication, experience, trust, attitude, business and marketing patterns. The objectives of this research are firstly, to study the positive change in brand communication through Facebook. Secondly, to understand that the 
changing consumer psychology by brand communication through Facebook.

\section{Methods}

The qualitative approach used in this study is based on systematic, carefully arranged and orderly analysis of secondary data. The review was based on classifying, characterizing, sorting and arranging the topic for understanding the review in each stream with deep insights. The review of literature method was used for this study. The researches from the period 2011-2017 related to the brand communication and changing consumer psychology through Facebook were taken into consideration. This strategy is utilized by numerous analysts for expressive investigation of different dimensions of the main study. The data collection tools like Journals, Magazines, Internet, research papers were used. In this research study, the researcher considered different innovative techniques used by different researchers recommended for future scope of study. The structural method is used with theoretical analysis and in- depth discussion to reach the common theme in different streams to emerge the essence of the study. The study is based on the working models of brand communication on Facebook. The application of information technology as well as the brand communication strategies used by brands are involved in this study. The study is not limited to these two streams. As one way, the study revolves around the concept of brand communication practices on Facebook, which talks about brand communication patterns and on the other way it is linked to the patterns of how customers are getting more interactive and engaged in branding strategies evolved by brands on Facebook which are deeply altering their psychology. In this research, the researcher considered and found out the platform to link all the streams and reach to the conclusion which has been done with the help of literature review as a methodology. The researcher has highlighted deep insights, logical and orderly analysis of available review and drawn conclusion based on deep study, analysis and understanding of available secondary research. The limitations of this study were that the researcher found it to be extremely hard to get reasonable and pertinent information which can be put stock in effortlessly from secondary sources at times. The subject of research is mix and merger of various streams including psychology, mass communication, data innovation and administration. The researcher thinks that it's hard to connect all the areas and to pick what to incorporate and what is to be overlooked while completing the exploration.

\section{Review of literature and Interpretation}

\section{Positivity in Brand Communication through Facebook}

Schivinski and Dabrowski (2015) revealed that brand communication created by brand as well as consumer effect brand consciousness/relations; however, brand communication created by users showed a positive effect on brand faithfulness and acknowledged quality of the brand. The message strategies most likely to advertise online through word of mouth for business-to-consumer (B2C) business-to-business (B2B) as well as Facebook product/service accounts. It was found that B2B Facebook posts by different accounts found to be more impactful if posts comprise company or business names and sidestep push sales mechanism or overtly saleable announcements. Moreover, it was recommended that including emotions and thoughts in Facebook posts predominantly used as an influential strategy for social media for service as well as B2B vendors. (Swani, Milne and Brown, (2013)). Pronschinske, Groza, and Walker (2012) examined the relationship between the Facebook page attributes found on Facebook pages of sports team and user (i.e., fan) involvement and revealed that Facebook page attributes were the signals of authenticity and consumer involvement and have the utmost influence on appealing and upholding a fan base on Facebook. The longitudinal Multi-Grounded Theory was used to examine three Fortune 110 companies, Delta Airlines, WalMart, and McDonald's for six weeks of Facebook Page messaging data testing data of 256 brand posts. The tested typology incorporates seven predominant message classes like brand awareness, corporate social responsibility, Client Service, Involvement, Product Consciousness, Advertising, and Seasonal with 23 sub-categories. A valuable theoretical and empirical opening point for edging Social Media marketing strategies, and for updating the design and development of fruitful Social Media advertising messages were revealed by Coursaris, Osch, and Balogh (2013). Saransomrurtai (2011) demonstrated the conversion into brand network through social network and usage of profile of a brand on Facebook as an operational advertising communiqué and stated that the fast development of interpersonal organization locales, for example, Facebook and My Space, has got a lot of consideration from both professionals and students. Many clients effectively take an interest on informal community locales. Facebook alone has more than 500 million enlisted clients. Advertisers have started to perceive and believes that these interpersonal organization locales as 
another road to advance their brands on the web. Top organizations and brands around the globe make their image profiles on well-known informal organization locales. The findings revealed that there is a relationship between brands' utilization of brand esteem and brand profile pages. The impact of liking a Facebook page on brand estimations was tested by making comparison between current brand page followers with non- and new followers. It was found that new fans on Facebook enhanced brand estimations. The causal (as opposed to correlational) impact of liking a brand on Facebook was shown and it was revealed that perceived conversational human voice describes these effects predicting the importance of interactivity of the brand on Facebook. There was a significant positive rise in new followers on brand estimations, whereas there was no change in non-followers. Present fans were most positive in estimations totally, but over time showed no change. This was evident to the fact that following a brand's Facebook updates of brands can cause changes in brand estimations positively as examined by Beukeboom, Kerkhof, and Vries (2015). Vries, Gensler, Leeflang (2012) demonstrated that the brand post admiration gets boosted by placing the post of the brand on the topmost of the brand fan page. Moreover, the results indicated that the number of likes and comments gets influenced by numerous stimuli. Specific, intense and communicating post by the brand physiognomies improve the quantity of likes. Additionally, the positive comments share on a post by the brand is positively linked to the quantity of likes. The comments' quantity can be boosted through the communicating post features. Both positive and negative comments' shares are positively interrelated to the comments' quantity. It was revealed that through the usage of web and social media sites there are huge assistances like a rise in alertness and inquisitiveness, improved associations with clienteles, a rise in the number of new customers, better capacity to target clienteles worldwide, and co-branding of indigenous brands that improve the brand personality of small brands in the area were investigated by Jones, Borgman and Ulusoy (2015). Patterson (2012) summarised through a meta-reflective approach endeavoured to collect and organize the different types of knowledge gathered from a vast accumulation of contemplative articles about Facebook penned by the very customers for whom it was invented. Eventually, the paper lights up the progression of the Facebook brand, and outlines how a metathoughtful approach can possibly be of great potential to customer researchers. The active handling of negative word of mouth in the social media has theatrical effect on user retention, bounces likely damage and advances profitability. The type of consumers' defensive behaviours within Facebook brand groups were examined. Information uncovers that guarded conduct is drilled inside Facebook, seeing that more various sorts of cautious practices are polished in high involvement products. Likewise, cautious practices are more pervasive inside utilitarian as opposed to hedonic brands found by Hassan and Ariño, (2016). Correia, Medina, Romo, and Espinosa, (2014) explained that the concentration these days keeps on being exceptionally associated with deals and advancements than focusing on conventional communication channels when brand should move to make collaborations with importance for the group of viewers through versatile content before concentrating on sales. Brands ought to consider the way they speak with their intended interest group and consider informal online organizations and mobile advancements as another method for extending the business, adjusting to the new shopper not examined by the customary advertising and communication media. Through content analysis investigation of 44 world's biggest brands as indicated by Interbrand to find the way they impart through Facebook divider posts and Twitter. Few brands were watched and showed an incredible environment with regards to making a fascinating situation by presenting content particularly on the brand group, however many brands could profit by making a more participative and engaging content in both Facebook and Twitter, and in addition being more receptive to their fans. These fans expected that they can create individual associations with brands via web-based networking media. Keeping up a connecting and responsive condition will turn out to be progressively imperative for the individuals who need to be at the forefront of the web-based social networking transformation and receive rewards, for example, brand dedication and trust of users involved in brand groups stated by Ryan, Peruta and Chouman (2013).

Jayasingh and Venkatesh (2015) revealed that bases for consumer involvement are contentrelated as well as occurrence of activities of brand posts and not fans following quantity. The exploration was advanced on a conceptual model of consumer involvement that improvises the concept understanding and offers the strategy foundation to upsurge their Facebook page engagement. The online involvement factors on brand Facebook pages. To give knowledge to 
experts willing to use informal communities for promoting purposes, his examination breaks down the affecting elements as far as attributes of the content imparted by the brands, for example, media sort, content sort, posting day and time, over the level of online client engagement measured by number of preferences, remarks and offers, and association term for the area of a Facebook brand page. The outcomes demonstrated that there is an alternate impact of the investigated factors over individual engagement measures as investigated by Cvijikj and Michahelles (2013). The method of clients' conversion into brand followers found that fan pages of brands on interpersonal organizations have turned out to be exceptionally prevalent online administrations. It was found that the reason for this examination was to explore the fan pages' impact on the buyer-brand relation also to find factors which rouses clients to participate. For this a system was produced considering traditional ideas of utilization and satisfaction hypothesis, client engagement, and inclusion hypothesis. It has demonstrated a huge impact from online administration use conduct on the brand fan page on the buyer-brand relation. Besides, distinctive esteems were taken, for example, useful and pleasing content as instigators of supporting fan-page investigated by Jahn, and Kunz, (2012). Seung-A and Jin, (2012) investigated advertising social media potential for management of high-end brands. The Structural Equation modelling examination revealed dynamic connections among customers' impression of worth expressive and social adjusting elements of extravagance businesses, fulfilment through an extravagance brand's Facebook page of Louis Vuitton, states of mind related to the brand, goals with respect to usage of the brands' web-based social networking sites for web-based shopping, and expectations to inquire about on the web. Lee, Kim and Kim (2011) explored the influence of brand online community on user's group involvement conducts like user created or promoter-created on Online Social media sites. The outcomes demonstrated that purchasers' online image group engagement aims were indirectly affected by the diverse sorts of groups through various levels of shoppers' attributions to characteristic thought processes of selflessness. This examination additionally found that, in the attribution forms, customers' inborn intentions of compassion roused them to recognize themselves socially with the online groups they join. At last, this investigation showed that the characteristic thought processes of unselfishness and having social identity inspirations gave solid social motivators to rouse customers to participate in brand online group practices. Kang, Tang and Fiore (2014) explored enhanced customer-brand relations on restaurant Facebook brand fan page increase customer welfares and increase dynamic involvement. The study revealed that brand followers are more likely to visit Facebook restaurant fan pages whenever followers obtain social-psychological and major benefits via Facebook page interactions. Subsequently entities can create concrete faith and responsibility toward eatery brands and gives future study scope for exploration of Facebook like a promoting apparatus and endorses brand management procedures for online groups' usage.

\section{Changing Consumer Psychology by brand communication through Facebook}

Goh, Heng and Lin (2013) investigated Brand Community on social media sites and behaviour of the consumer by quantifying the Comparative Influence of User- and Marketer-Generated Content and established that online networking brand groups' involvementstimuluses a positive increase in consumptions of buying. User Generated Content (UGC) as well as Market Generated Content (MGC) effects confirmed online interaction content proof persuading shopper buy manner via installation of data and impact. It was found that online advertisements pull in less consideration levels than friend's' suggestions. Results demonstrated that factually there is no distinction in promotions seen and clicked amongst ladies and men as demonstrated by Barreto (2013). Chen, Fay and Wang (2011) investigated the marketing role in social networking web to find out that how users review online changes and also studied relationships between posting behaviour of users on Facebook and advertising variables by analysing 2001 and 2008 automobile data from leading user review source. It was revealed that advertising variables influences the capacity and valence of online postings while price and quality of the Product have very different impacts on posting intents. Furthermore, it was found that augmented Internet and user review site usage has changed these associations. The aspects which influences users' liking and stating behaviour proceedings on Facebook brand pages and confirmed the significance of facilitating part of approach of interface taking place on relationships amongst different character traits as well as commenting/ liking behaviour. The study took 269 respondents online from the national survey, aged 18 to 32 . The study revealed that two approaches of interaction acted as mediators 
between Facebook liking/ commenting behaviours and three personality traits investigated by Kabadayi and Price (2014). Luarn, Lin and Chiu (2015) tested the impact on online involvement of brand Facebook pages by various characteristics of brand posts. There was significant effect found on user online involvement through content type of media and content of brand posts. In this research comment, likes and shares were used like a degree of online users' engagement to lay down the novel marvels. The binding links by discovering new drives for connecting on Facebook. The consumer drives for involving in sharing link via Facebook, finding purposes that extend outside those of past research were emphasized in this research. The considerations of the effect of those drives on linking frequency, and content, presenting drives that adding to current viewpoints of social network sites as data hubs were stressed upon by taking 217 Facebook users and found that chief drive for Facebook linking was information sharing. The users also post links for ease and amusement, passing time, social utility, control, and endorsing work. It was also revealed that users who wish to share information, with higher education and were interested in promoting their work post job-related and other links explored by Baek, Holton, Harp and Yaschur (2011). Hollenbeck and Kaikati (2012) tested how shoppers utilize brands on Facebook to speak to the self by using a multi-strategy approach using subjective research strategies. Findings explained that buyers express both their genuine and perfect selves as well as Facebook contextualize selfarticulation as compatible and non- compatible characters. The engagement of user on Facebook brand community was explored by Gummerus, Liljander, Weman, and Pihlström, (2012). The research has put light on the impact of client engagement practices on expected relationship advantages and results. By taking an online review of individuals from a gaming brand Facebook group, bringing about 276 working reactions from clients revealed that buyer involvement was categorised into "community Engagement Behaviours" (CEB) and "Value-based Engagement Behaviours" (TEB). Moreover, three relational benefits were distinguished: social advantages, stimulation welfares as well as financial advantages. The involvement practices affected the advantages got. Moreover, the mediation analysis outcomes have shown that entertainment benefits partially mediate the influence of CEB on fulfilment, whereas the result of TEB on gratification is fully mediated via similar welfares. The impact of CEB is mediated by Entertainment benefits on loyalty. Yang (2012) has studied decision making conduct of users on Facebook by taking 256 Face bookers on smart phones as research tests, and the theories were tried utilizing regression analysis. The examination discoveries proposed that promoting messages gave by dear companions just influence customer brand states of mind, however publicizing messages by brands sources influence both buyer brand dispositions and purchasing expectations. Utilitarian and recreational publicizing messages influence buyer promoting state of mind, brand attitudes, buying expectations and contribution. In conclusion, purchaser participation partially mediates the impacts of utilitarian publicizing and recreational promoting on advertising attitudes, brand states of mind and acquiring goals. Lin and $\mathrm{Lu}$ (2011) stated that informal community locales empower clients to convey what needs be, set up ties, and create and keep up social connections. As of late, many brands have started utilizing web-based social networking personality (e.g., Facebook fan pages) to upgrade brand appeal and engaging quality, and interpersonal social media sites have advanced into social utility systems, along these lines making various promising business openings. To this end, the administrators of fan pages should know about the variables inspiring clients to proceed with their patronization of such pages. This investigation set out to distinguish these spurring factors from the perspective of social capital. This examination utilized structural equation modelling to explore a research model in view of a review of 327 fan pages clients. This examination found that ties identified with social cooperation (auxiliary measurement), shared esteems (psychological measurement), and trust (social measurement) assume pivotal parts in clients' continuation with expectation to utilize Facebook fan pages.

Chu (2013) explored viral promotions in social media by focusing involvement of users in Facebook Groups and checking outcomes among College-going Users. This study was focused at the budding linking of Facebook amass investment with viral publicizing responses. The findings recommended that school passed Facebook entities participated in extra raised extents of self-exposure as well as keeping up additional perfect states of mind towards social networking based on web and promulgation in general than non-group entities. Facebook involvement by the group does not apply an influence on customers' viral endorsing passing on procedures. The results additionally identify diversities in indicators of passing on procedures between members of the group and non- 
members. Wallace, Buil, Chernatony (2012) inspected theories coordinating social parts of informal organizations, self-expressive brands and shoppers' image support and loyalty towards brands and investigated the connection amongst gay people and social bonds, and the degree to which solid bonds are related with Facebook clients' consolidation of self-expressive brands by 'Loving' them in their own profiles. They likewise analysed the connection between self-expressive brands 'Preferred' on Facebook, and buyers' image support in on the web and disconnected settings. A study of 265 Facebook clients uncovered more grounded social binds affecting shoppers to 'Like' brands that express their inward and social identities. Brands which are self-expressive mirroring one's inward or social self-urged buyers to propose a positive verbal exchange on interpersonal organizations. Moreover, self-expressive brands 'Preferred' on Facebook absolutely impact buyers' reception of brand acknowledgment, and their eagerness to excuse 'Loved' brands for misconduct Ho, (2014) explored Facebook consumer behaviour and investigated that whether consumer participation brings consumer evaluation of the brand positively or not. It demonstrated consumers' intended behaviours on Facebook by exploring how involvement of communities impacts buyer social responsibility behaviours regarding brand. Furthermore, it has shown the mediating effect by taking brand conviction as well as identity of the communal. It was revealed that consumers' communal involvement on Facebook has directly positive and significant impact on trust on brand and communal identity. It was confirmed that trust on brand has directly positive and significant impact on identity of the community the results also shown that trust on brand and uniqueness of the communal play a mediating role between involvement on Facebook and buyer citizenship conducts. Facebook enables breaching of Social Norms to better understand how consumers enjoy Facebook usage and breaks the tension among their longing to observe and the social norm saying one should not observe was investigated. 11 users of Facebook were involved, observed and interviewed about their online time spending and discussed posts that they had gazed at recently. It was discovered that gazing has normal place on Facebook and extended from inoffensive data looking to more outrageous types of Schadenfreude Staring. Notwithstanding the gazing conduct, the inspiration stayed consistent. That is, Facebook enabled the clients to participate in conduct that is frequently criticized in disconnected settings quoted by Veer (2011). Peitro and Pantano (2012) done an empirical study of social web effect on consumer buying decision by taking the case of Facebook. The discoveries affirm that happiness is a key determinant of informal communities' utilization as device for supporting the buying choice. This exploration moves beyond informal communities' utilization to factors identified with the Facebookmediated advertising interchanges, by giving significant information on the heaviness of this channel for the advancement of new direct advertising systems. Hunt, Atkin and Krishnan (2012) examined the stimulus of computer facilitated communiqué anxiety on motivations for usage of the Facebook communicating features. It was found that communiqué anxiety in a computer interceded setting was revealed to be inversely linked to relational, assertiveness, entertaining, and time passing motivations for Facebook usage. Relational communiqué, selfexpression, and entertaining reasons all significantly foretold usage of Facebook communicating features. Harris and Dennis (2011) explored the rising co operations amongst young purchasers and shopper stuffs/administrations on familiar societies. They focused at the extent to which a little investigative sample of members is eager to join communal buying demeanour article/advantage proposals and retail buying practices. The findings recommended that Facebook is a consumer engagement engine which modifies behaviour which specify the genuine online shopping conduct.

\section{Discussion}

The intricate information has been rearranged and displayed in orderly way It has not only make the research easier and interesting but also help in gaining deep insights into the effective brand communication process on Facebook and consumer psychology towards Facebook usage After evaluating and assessing the theoretical literature from different sources- academic and non- academic information available including print and electronic as well as all the secondary resources, the researcher found that the Facebook has become the indispensable part of everyone's life. It has not connected only minds but has become a binding force by providing a premium stage for branding, expression, connect, experience and trust. It was found that business created, and consumer produced content on Facebook strongly impact brand consciousness and relations and consumer generated content positively affect brand loyalty and perceived brand equity as it was found more trustworthy. Facebook helps to caters increased level of alertness and enquiries, improvises customers' 
relations, up surging new client. It enhances brands' reaching ability to customers worldwide. It helps in co-advertising of indigenous brands that improve brand image of small businesses also. When brand Facebook page is followed it can cause positive change in brand evaluation and intensifies brand interactivity on Facebook. Interpersonal communication, self-expression and entertainment motives behind the content posted on Facebook were found to be the interactive features on Facebook. Extreme convenience and ready handiness impacts brand experience tremendously and generate and rapidly spread Eword of mouth through Facebook pages in forms of comments, reviews and recommendations which helps in framing brand image on the public stage automatically and helps in making perception of the brand in more transparent way. Rational aspects of social networks were found to be self-advocacy and consumer's brand advocacy. When Facebook page is liked by the consumer/user then they can express their inner and social selves with greater ease which signifies consumer brand acceptance is the result. Facebook has a strong relation with brand network and brand profile pages directly leads to the enhancement of brand esteem. The consumer psychology is deeply and positively affected by these factors.

\section{Conclusions}

On the premise of literature reviewed, the outcomes revealed that Facebook gives an augmented base to brands and appealing and enticing platform to consumers for their engagement .It gives brands a competitive and marketing edge to consumer research and upholding global fanbase Facebook gives opportunities to brands to explore and play with the content of brand posts to make them more effective and consumer centric which further lays a concrete foundation to strong and convincing brand strategies. The brand updates on Facebook causes positive changes in brand estimations for the brands on Facebook which gives a clear view and perspective to brand communication operated at Facebook. The study has also revealed that there is a strong relationship between brand profile page content and brand esteem which clearly proves first hypothesis of this research which states that that brand communication is positively affected by Facebook.

It was revealed that user generated content has more solid influence on consumer buying intent as it was generated by global users and serves as a mark of reliability. The brand communication approach acts as a mediator of Facebook liking and commenting behaviours and their personality traits. The comments, likes and shares are used as a degree of user's online Facebook engagement which lays new foundations to brand image and brand communication involving consumer participation and activity. The advertising variables influences capacity and valence of online postings of consumers. It was revealed that augmented Facebook brand communication and Facebook usage has altogether associations of consumer relationship with the brand attributes and personality. The consumers can express themselves genuinely as Facebook provides context for compatible and non-compatible characters which helps the buyers to express easily and expressively. Interactivity on Facebook is predicted by more interpersonal communication by consumers, self-expression and entertainment motives. It was found that selfexpressive brands when liked by the consumers affects positively on their brand acceptance. Facebook found to be the consumer engagement engine which not only modifies their buying intents as it changes the overall psychology of the consumers. It was concluded that Facebook brand communication enables consumer participation and engagement with the brands which changes their overall lifestyle and buying intents which proves the second hypotheses of the study which stated that there is positive change in consumer psychology by brand communication through Facebook.

Branding on Facebook nowadays has become the most important part of business lifeline. Facebook gives maximum visibility, connect and rich experience of the brand which makes the brand 'feel' online. It caters to the virtual experience of the brand just a click away. It was found that Facebook is a consumer engagement engine which specifies and modifies the genuine buying online intents. The brand image emerged with the innovative, premium strategies and patterns launched by brands on the Facebook is the result of behaviour indices that possess attention of the brand much more than buying resultant from inspirational enticers like 'liking', 'sharing' and 'recommending' the brand page or any attribute of brand, it result in the acceptance of brand by the consumer and content get exposed to consumer and vice-versa. Facebook identity of the brand serves as a lubricant as consumers have different connection strategies. that the key determinants for shopper engagement are content-related and recurrence of brand posting exercises and not on number of fans taking after the page. Facebook serves a premium lubricant to brand as it provides identity and personality to 
the brands which helps to impact consumer's mindsets in a desired way. The content involving posts, events, campaigns, images, videos plays a significant role in influencing buying intents and perceptions of consumers. The content on the Facebook serves as a weapon to the brands to play their part with 360-degree approach catering to all aspects of the consumer behaviour. Then brand experience which is provided on Facebook in the form of interpersonal communication and giving more opportunities to consumers for self expression with great ease and accessibility influence the touch points of consumers which bring major engagement and connect with the brands. If consumers like, share or recommend the brands on Facebook it is signified that they are exposed to the content and have accepted the brand with their heart which results in new followers liking of the brand Facebook pages. All this result in brand success and customer trust and loyalty if brand content and connect satisfies the manifestations of the consumer behaviour. There is a need to explore different dimensions of the study. With the diffusion of new and innovative technology and its everyday innovated features Facebook gives immense opportunities to develop brand personality and creation of brand trust in the heart of the consumers and lays down a deep impact on their minds resulting in changed lifestyle and aspirations from the brand as Facebook communication serves almost all functions from information to web of shopping to after sales services and has made branding more innovative, interesting and challenging in today's time. In this area of research there is great scope for exploratory statistics and research.

\section{References}

Annie Jin, S. A. (2012). The potential of social media for luxury brand management. Marketing Intelligence $\mathcal{E}$ Planning, 30(7), 687-699.

Baek, K., Holton, A., Harp, D., \&Yaschur, C. (2011). The links that bind: Uncovering novel motivations for linking on Facebook. Computers in Human Behavior, 27(6), 2243-2248.

Beukeboom, C. J., Kerkhof, P., \& de Vries, M. (2015). Does a virtual like cause actual liking? How following a Brand's Facebook updates enhances brand evaluations and purchase intention. Journal of Interactive Marketing, 32, 26-36.

Chen, Y., Fay, S., \& Wang, Q. (2011). The role of marketing in social media: How online consumer reviews evolve. Journal of Interactive Marketing, 25(2), 85-94.

Chu, S. C. (2011). Viral advertising in social media: Participation in Facebook groups and responses among college-aged users. Journal of interactive advertising, 12(1), 30-43.

Coursaris, Osch,\& Balogh (2013, June). A Social Media Marketing Typology: Classifying Brand Facebook Page Messages for Strategic Consumer Engagement. In ECIS (p. 46).

Cvijikj, I. P., \&Michahelles, F. (2013). Online engagement factors on Facebook brand pages. Social Network Analysis and Mining, 3(4), 843-861.

De Vries, L., Gensler, S., \&Leeflang, P. S. (2012). Popularity of brand posts on brand fan pages: An investigation of the effects of social media marketing. Journal of interactive marketing, 26(2), 83-91.

Di Pietro, L., \&Pantano, E. (2012). An empirical investigation of social network influence on consumer purchasing decision: The case of Facebook. Journal of Direct, Data and Digital Marketing Practice, 14(1), 18-29.

Goh, K. Y., Heng, C. S., \& Lin, Z. (2013). Social media brand community and consumer behavior: Quantifying the relative impact of user-and marketer-generated content. Information Systems Research, 24(1), 88-107.

Gummerus, J., Liljander, V., Weman, E., \&Pihlström, M. (2012). Customer engagement in a Facebook brand community. Management Research Review, 35(9), 857-877.

Harris, L., \& Dennis, C. (2011). Engaging customers on Facebook: Challenges for e-retailers. Journal of Consumer Behaviour, 10(6), 338-346.

Hassan, M., \&CasalóAriño, L. V. (2016). Consumer devotion to a different height: How consumers are defending the brand within Facebook brand communities. Internet Research, 26(4), 963-981.

Ho, C. W. (2014). Consumer behavior on Facebook: does consumer participation bring positive consumer evaluation of the brand? Euro Med Journal of Business, 9(3), 252267.

Hollenbeck, C. R., \&Kaikati, A. M. (2012). Consumers' use of brands to reflect their actual and ideal selves on 
Facebook. International Journal of Research in Marketing, 29(4), 395-405.

Hunt, D., Atkin, D., \& Krishnan, A. (2012). The influence of computer-mediated communication apprehension on motives for Facebook use. Journal of Broadcasting $\mathcal{E}$ Electronic Media, 56(2), 187-202.

Jahn, B., \& Kunz, W. (2012). How to transform consumers into fans of your brand. Journal of Service Management, 23(3), 344-361.

Jayasingh, S., \& Venkatesh, R. (2015). Customer Engagement Factors in Facebook Brand Pages. Asian Social Science, 11(26), 19.

Jones, N., Borgman, R., \&Ulusoy, E. (2015). Impact of social media on small businesses. Journal of Small Business and Enterprise Development, 22(4), 611-632.

Kabadayi, S., \& Price, K. (2014). Consumer-brand engagement on Facebook: liking and commenting behaviors. Journal of Research in Interactive Marketing, 8(3), 203-223.

Kang, J., Tang, L., \& Fiore, A. M. (2014). Enhancing consumer-brand relationships on restaurant Facebook fan pages: Maximizing consumer benefits and increasing active participation. International Journal of Hospitality Management, 36, 145-155.

Lee, D., Kim, H. S., \& Kim, J. K. (2011). The impact of online brand community type on consumer's community engagement behaviors: Consumer-created vs. marketercreated online brand community in online social-networking web sites. Cyberpsychology, Behavior, and Social Networking, 14(1-2), 59-63.

Lin, K. Y., \& Lu, H. P. (2011). Intention to continue using Facebook fan pages from the perspective of social capital theory. Cyberpsychology, Behavior, and Social Networking, 14(10), 565-570.

Luarn, P., Lin, Y. F., \& Chiu, Y. P. (2015). Influence of Facebook brand-page posts on online engagement. Online Information Review, 39(4), 505-519.

Margarida Barreto, A. (2013). Do users look at banner ads on Facebook? Journal of Research in Interactive Marketing, 7(2), 119-139.

Patterson, A. (2012). Social-networkers of the world, unite and take over: A metaintrospective perspective on the Facebook brand. Journal of Business Research, 65(4), 527534.

Pereira Correia, P., García Medina, I., Fabiola González Romo, Z., \& S. Contreras-Espinosa, R. (2014). The importance of Facebook as an online social networking tool for companies. International Journal of Accounting \& Information Management, 22(4), 295-320.

Pronschinske, M., Groza, M. D., \& Walker, M. (2012). Attracting Facebook'fans': the importance of authenticity and engagement as a social networking strategy for professional sport teams. Sport marketing quarterly, 21(4), 221.

Ryan, W., Peruta, A., \&Chouman, S. (2013, October). Social media and the transformation of brand communication. In Proceedings of International Conference on Making Sense of Converging Media (p. 146). ACM.

Saransomrurtai, C. (2011). Converting a social network into a brand network: How brand profile on Facebook is used as an online marketing communication tool (Doctoral dissertation, Auckland University of Technology).

Schivinski, B., \&Dabrowski, D. (2015). The impact of brand communication on brand equity through Facebook. Journal of Research in Interactive Marketing, 9(1), 31-53.

Swani, K., Milne, G., \& P. Brown, B. (2013). Spreading the word through likes on Facebook: Evaluating the message strategy effectiveness of Fortune 500 companies. Journal of Research in Interactive Marketing, 7(4), 269-294.

Veer, E. (2011). Staring: How Facebook facilitates the breaking of social norms. In Research in Consumer Behavior (pp. 185-198). Emerald Group Publishing Limited.

Wallace, E., Buil, I., \& De Chernatony, L. (2012). Facebook 'friendship 'and brand advocacy. , 128-146.

Yang, T. (2012). The decision behavior of Facebook users. Journal of Computer Information Systems, 52(3), 50-59.

Wiki article (NA, ND) - www.wikipedia.com, www.dictionary.com, www.shabdkosh.com, www.cambridge.dictionary.com, www.searchengine.com. www.afaqs.com 